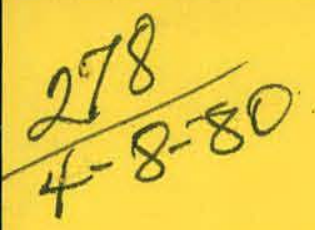

\title{
MASTER
}

\section{Biological Removal of Organic Constituents \\ in Quench Water from a Slagging, Fixed-Bed Coal-Gasification Pilot Plant}

V. C. Stamoudis and R. G. Luthy 


\section{DISCLAIMER}

This report was prepared as an account of work sponsored by an agency of the United States Government. Neither the United States Government nor any agency Thereof, nor any of their employees, makes any warranty, express or implied, or assumes any legal liability or responsibility for the accuracy, completeness, or usefulness of any information, apparatus, product, or process disclosed, or represents that its use would not infringe privately owned rights. Reference herein to any specific commercial product, process, or service by trade name, trademark, manufacturer, or otherwise does not necessarily constitute or imply its endorsement, recommendation, or favoring by the United States Government or any agency thereof. The views and opinions of authors expressed herein do not necessarily state or reflect those of the United States Government or any agency thereof. 


\section{DISCLAIMER}

Portions of this document may be illegible in electronic image products. Images are produced from the best available original document. 
The facilities of Argonne National Laboratory are owned by the United States Government. Under the terms of a contract (W-31-109-Eng-38) among the U. S. Department of Energy, Argonne Universities Association and The University of Chicago, the University employs the staff and operates the Laboratory in accordance with policies and programs formulated, approved and reviewed by the Association.

\section{MEMBERS OF ARGONNE UNIVERSITIES ASSOCIATION}

The University of Arizona

Carnegie-Mellon University

Case Western Reserve University

The University of Chicago

University of Cincinnati

Illinois Institute of Technology

University of Illinois

Indiana University

The University of Iowa

Iowa State University
The University of Kansas

Kansas State University

Loyola University of Chicago

Marquette University

The University of Michigan

Michigan State University

University of Minnesota

University of Missouri

Northwestern University

University of Notre Dame
The Ohio State University

Ohio University

The Pennsylvania State University

Purdue University

Saint Louis University

Southern Illinois University

The University of Texas at Austin

Washington University

Wayne State University

The University of Wisconsin-Madison

\section{NOTICE}

This report was prepared as an account of work sponsored by an agency of the United States Government. Neither the United States Government or any agency thereof, nor any of their employees, make any warranty, express or implied, or assume any legal liability or responsibility for the accuracy, completeness, or usefulness of any information, apparatus, product, or process disclosed, or represent that its use would not infringe privately owned rights. Reference herein to any specific commercial product, process, or service by trade name, mark, manufacturer, or otherwise, does not necessarily constitute or imply its endorsement, recommendation, or favoring by the United States Government or any agency thereof. The views and opinions of authors expressed herein do not necessarily state or reflect those of the United States Government or any agency thereof.

Printed in the United States of America

Available from

National Technical Information Service

U. S. Department of Commerce

5285 Port Royal Road

Springfield, VA 22161

NTIS price codes

Printed copy: A03

Microfiche copy: A01 
Distribution Category:

Coal Conversion and Utilization--

Coal Gasification (UC-90c)

ANL/ PAG-1

ARGONNE NATTONAL LABORATORY

9700 South Cass Avenue

Argonne, Illinois 60439

BIOLOGICAL REMOVAL OF ORGANIC CONSTITUENTS

IN QUENCH WATER FROM A SLAGGING, FIXED-BED

COAI,GASIFICATION PILOT PLANT

by

Vassilis C. Stamoudis and Richard G. Luthy*

Energy and Environmental Systems Division

Pollutant Analysis and Geochemistry Section

February 1980

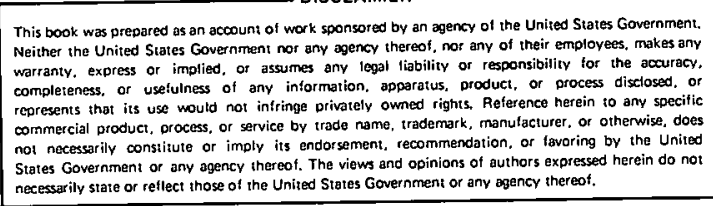

Work Sponsored by

U. S. Department of Energy

Asșistant Secretary for Fossil Energy

Office of Fossil Energy

*Department of Civil Engineering, Carnegie-Mellon University 
ABSTRACT. . . . . . . . . . . . . . . . . . .... 1

1 INTRODUCTION . . . . . . . . . . . . . . . . . . 1

2 FIELD AND LABORATORY PROCEDURES. . . . . . . . . . . . . 2

2.1 Quench Water Selection, Collection, and Storage . . . . . . 2

2.2 Quench Water Pretreatment . . . . . . . . . . . . 3

2.3 Biological Treatment. . . . . . . . . ....... 3

2.4 Extraction Procedures and GC/MS Analysis. . . . . . . . . . 3

3 EXXPRIMENTAL RESULTS . . . . . . . . . . . . . . . . 6

3.1 Biological Reactor Characteristics. . . . . . . . . . 6

3.2 Removal Efficiency of Organic Constituents. . . . . . . . 6

4 DISCUSSION . . . . . . . . . . . . . . . . . 6

4.1 Acid Fractions. . . . . . . . . . . . . . . . . 6

4.2 Base Fractions. . ..................... 15

4.3 Neutral Fractions . . . . . . . . . . . . . . 15

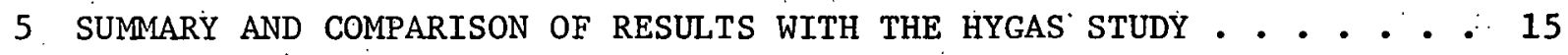

6 CONCLUSTONS AND RECOMMENDATIONS. . . . . . . . . . . . . . 16

ACKNOWLEDGMENTS . . . . . . . . . . . . . . . . . . . . 17

REFERENCES. . . . . . . . . . . . . . . . . . . . . 17 


\section{LIST OF FIGURES}

No.

2.1.Extraction Scheme for Biological Reactor Influent and

- Effluent Samples. . . . . . . . . . . . . . . . . .

3.1 Tota1-Ion Chromatograms of Influent and Effluent Acid-Fraction Extracts of: Biologically Treated GFETC Slagging, Fixed-Bed Coal-Gasification Quench Water. . . . . . . . . . . . . 8

3.2 Total-Ion Chromatograms of Influent and Effluent Base-Fraction Extracts of Biologically. Treated GFETC Slagging, Fixed-Bed Coal-Gasification Quench Water. . . . . . . . . . . . . 9

3.3. Total-Ion Chromatograms of Influent and Effluent Neutral-Fraction Extracts of Eiologically Treated GFETC Slagging Fixed-Bed Coal-Gasification Quench Water. . . . . . . . . . .. . 10

\section{LIST OF TABLES}

2.1 Representative Raw Quench Water Characteristics during Biological oxidation Studies. . . . . . . . . . . . . . . . . . 4

2.2 Percent Recoveries of Organics Extracted from Spiked Distilled Water Based on GC Analysis. . . . . . . . . . . . . . 5

3.1 Average Biological Reactor Performance Data for Evaluation of Removal of Trace Organic Compounds . . . . • . . . . : . . . . 7

3.2 Concentration in Biological Reactor Influent and Effluent and Percent Removal of Acid-Fraction Úrganics in GFETC Slagging, Fixed-Bed Coal-Gásification Quench Water. . . . . . . 11

3.3 Concentration in Biological Reactor Influent and Effluent and Percent Removal of Base-Fraction Organics in GFETC Slagging, Fixed-Bed Coal-Gasification Quench Water... . . . . 12

3.4 Concentration in Biological Reactor Influent and Effluent and Percent Removal of Neutral-Fraction Organics in GFETC Slagging, Fixed-Bed Coa1-Gasification Quench Water. . . . . . . 13 


\title{
BIOLOGICAL REMOVAL OF ORGANIC CONSTITUENTS IN \\ QUENCH WATER FROM A SLAGGING, FIXED-BED \\ COAL-GASIFICATION PILOT PLANT
}

\author{
by \\ $r$ \\ Vassilis C. Stamoudis and Richard G. Luthy
}

\section{ABSTRACT}

This study is part of an effort to assess the efficiency of activated-sludge treatment for removal of organic constituents from high-Btu coal-gasification pilot-plant quench waters. A sample of raw-gas quench water was obtained from the Grand Forks Energy and Technology Center's pilot plant, which employs the slagging, fixed-bed gasification process. The quench water generated in the processing of Indian Head lignite was pretreated to reduce ammonia and alkalinity, and then diluted and subjected to long-term biological treatment, followed by detailed characterization and analysis of organic constituents.

The pretreated (influent) and treated (effluent) samples were extracted using a methylene chloride, $\mathrm{pH}$-fractionation method to obtain acid, base, and neutral fractions, which were analyzed by capillary-column gas chromatography/mass spectrometry (GC/MS). Over $99 \%$ of the total extractable and chromatographable organic material in the influent acid fraction was composed of phenol and alkylated phenols. Biological treatment removed these compounds almost completely. Major components of the influent base fraction were alkylated pyridines, anilines, aminopyrroles, imidazoles and/or pyrazoles, diazines, and quinolines. Removal efficiency of these compounds ranged between 90 and 100\%. The influent neutral fraction was composed mainly of cycloalkanes, cycloalkenes, naphthalene, indole, acetophenone, and benzonitrile. Alkylated benzenes were generally absent. Removal efficiencies of these compounds were generally very good, except for certain alkylated cycloalkanes and cycloalkenes. Results are compared with those of a similar" study on HYGAS coal-gasification quench water.

\section{INTRODUCTION}

This study is a continuation of a cooperative program between Argonne National Laboratory (ANL) and Carnegie-Mellon University (C-MU), conducted with the assistance of the Institute of Gas Technology (IGT) and Grand Forks Energy and Technology Center (GFETC). The objectives of these studies are to characterize process effluents and to evaluate the efficiency of biological treatment for removal of organic constituents present in quench waters from high-Btu coal-gasification pilot plants.

A study of biological treatment for removal. of organic contaminants in quench waters from the IGT HYGAS coal-gasification pilot plant has been completed and published by ANL (Stamoudis et al., 1979). The results of that 
study showed activated-sludge treatment effectively removed the majority of organic constituents with the exception of certain constituents in the base and neutral fractions. The sample chosen for the present investigation was a quench water from the GFETC slagging, flxed-bed (SFB) coal-gasification pilot plant. One objective of the present study was to compare composition and component removal efficiencies of HYGAS and SFB process condensates. These pilot-plant quench waters, while not strictly representative of wastewaters that would be expected in a demonstration or commercial. scale HYGAS or SFB coal-gasification plant, provide useful information to evaluate the efficiency of biological oxidation for removal of organic constituents.

HYGAS and SFB process condensates have been chosen for these investigations because:. (1) these processes are representative of major Department of Energy-sponsored coal-gasification systems in an advanced state of development, (2) the processes produce process waters contaminated with organic pollutants, and (3) the basic biological treatability characteristics of these waters have been the subject of recent experimental investigations (Luthy and Tallon, 1978; Luthy et al., 1979).

A literature review has revealed that only limited information exists on characterization and removal of organic contaminants in coal-gasification condensates. Singer et al. (1978 and 1979) have summarized available characterization data and have initiated preliminary biological treatability studies on synthetic mixtures. Additional characterization data are provided by White and Schmidt (1978) on volatile, polar organics in by-product waters from two gasification processes, SYNTHANE and SFB. Dark (1979) has presented results of analysis of aromatic hydrocarbons in biologically treated process water from an unspecified coal-gasification process.

\section{FIELD AND LABORATORY PROCEDURES}

A description of the GFETC-SFB pilot-plant effluent flow-distributions and pilot-plant test program is provided by Ellman et al. (1979). Test conditions for the pilot-plant run from which quench waters were obtained are also described. Procedures employed for handling and processing of raw quench water are detailed by Luthy', Sekel, and Tallon (1979). These procedures are summarized below.

\subsection{QUENCH WATER SELECTION, COLLECTION, AND STORAGE}

The water used in this study was GFETC-SFB coal-gasification raw-gas quench water generated during gasifier run RA-52 using Indian Head Iignite. Approximately 250 gal of decanted quench water was shipped to C-MU from GFETC via freezer truck. Raw quench water was shipped and stored in 5-gal plastic

containers. Since it was necessary to provide means for long-term storage of raw quench water, the samples were preserved by freezing until needed as feed for the biological reactors. Although no studies were performed to assess the stability of trace organics in frozen samples, a recent study regarding the stability of HYGAS quench waters suggests that the extractable/ chromatographable components are stable up to at least 60 days under refrigeration (Raphaelian and Harrison, 1979). 


\subsection{QUENCH WATER PRETREATMENT}

Representative raw quench water characteristics for the samples used are given in Table 2.1. The quench water was pretreated to reduce excess alkalinity and ammonia concentrations by lime addition and air stripping. This pretreatment simulated ammonia removal as may be utilized in a commercial treatment train. It was found that ammonia-stripped quench water could not be processed through a biological reactor at full strength. However, a series of sequential and parallel tests with stripped SFB effluent in which feed strength and loading were varied independently demonstrated that stable biological reactor performance could be achieved by diluting ammonia-stripped quench water to $33 \%$ strength. .

\subsection{BIOLOGICAL TREATMENT}

The biological reactor employed in this study was a complete-mix, single-stage, air-activated sludge reactor with an internal clarifier. This reactor was operated under conditions whereby hydraulic residence time, mean bacterial-cell residence time, and feed strength were held as experimental constants. Dependent variables were steady-state values of mixed-1iquor volatile suspended solids (MLVSS) and effluent substrate concentration. The biological reactor was acclimatized to the quench water over a period of time such that the reactor was subjected to three complete bacterial sludge wasting cycles prior to the collection of steady-state performance data. The reactor was then operated for seven weeks during which two-week composite samples were collected for trace-organic analysis. The composite samples were collected in glass containers and shipped immediately to Argonne National Laboratory, where they were refrigerated prior to extraction.

\subsection{EXTRACTION PROCEDIJRES AND GC/MS ANALYSIS}

The extraction scheme used is presented in Fig. 2.1. This scheme employs $\mathrm{pH}$-fractionation into acid, base, and neutral fractions, and follows generally accepted protocols. Details of the extraction scheme are given in Stamoudis et a1. (1979). One liter of influent and $4 \mathrm{~L}$ of effluent were extracted with methylene chloride. Emulsion problems during extraction were minimized by successive freezing and thawing.

GC/MS analysis of organic constituents was performed as described in Stamoudis et al. (1979). Compound identifications were based on mass spectra and known retention times. Percentage removal of compounds was estimated by comparison of total-ion chromatograms of influent and effluent. This method assumes that the concentration levels of compounds were in the optimum range of linearity with respect to total-ion (or single-ion) areas as a function of concentration, and that extraction yields for compounds in the influent and effluent were the same.

Extraction efficiency was evaluated by extracting a standard mixture in distilled water containing acid, base, and neutral organic compounds. Results of percent recovery of 16 organic compounds are given in Table 2.2. Average recovery for the 16 compounds was $84 \%$.

Ten organic compounds were used as models to develop total-ion (or single-ion) areas as a function of concentration relationships for estimation 
Table 2.1 Representative Raw Quench Water Characteristics during Biological Oxidation Studies

\begin{tabular}{|c|c|c|}
\hline Parameter & & $\begin{array}{c}\text { SFB }{ }^{b}, c \\
(\text { Run RA-52) }\end{array}$ \\
\hline COD & & 25,400 \\
\hline Phenolics & & 5,100 \\
\hline $\mathrm{NH}_{3}-\mathrm{N}$ & & 5,200 \\
\hline $\mathrm{NO}_{3}$ & & $<2$ \\
\hline Organic-N & & 90 \\
\hline $\mathrm{CN}_{\text {tot }}^{-}$ & & 12 \\
\hline $\mathrm{SCN}$ & & 140 \\
\hline$s^{2-}$ & & 150 . \\
\hline $\mathrm{SO}_{4}{ }^{2-}$ & & 150 \\
\hline $\mathrm{P}$ & & 13 \\
\hline Alkalinity $\left(\right.$ as $\left.\mathrm{CaCO}_{3}\right)$ & & 18,400 \\
\hline Total Acidity. (as $\mathrm{CaCO}_{3}$ ) & & 24,000 \\
\hline Total Oil \& Grease & & 300 \\
\hline Soluble Oil \& Grease & & 190 \\
\hline Conductivity $(\mu \mathrm{mhos} / \mathrm{cm})$ & & 20,000 \\
\hline pH (units) & & 8.4 \\
\hline
\end{tabular}

${ }^{a}$ All units in mg/L except as noted.

${ }^{b}$ SPB data from Luthy, Sekel and Tallon (1979).

CDouble-decanted gasifier quench condensate. 


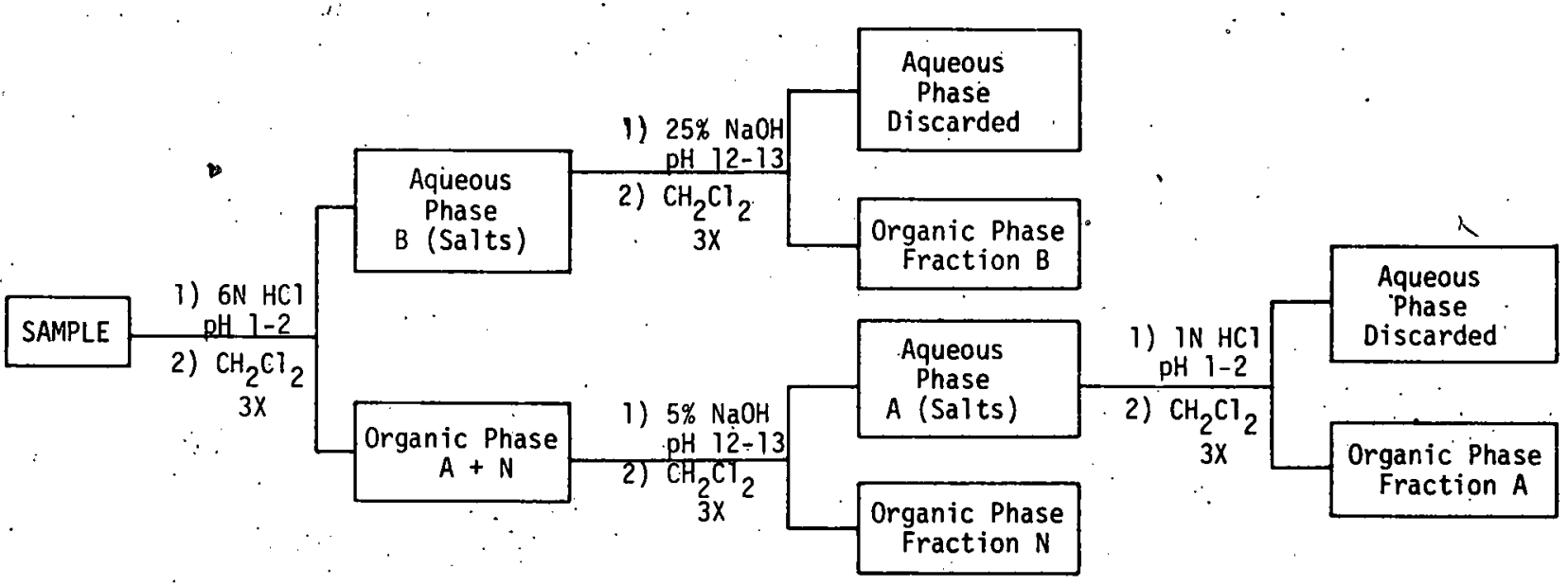

Fig. 2.1 Extraction Scheme for Biological Reactor Influent and Effluent Samples

Table 2.2 Percent Recoveries of Organics Extracted from Spiked Distilled Water Based on GC Analysis

\begin{tabular}{lc}
\hline \multicolumn{1}{c}{ Compound } & $\%$ Recovery \\
\hline o-Xylene & $65^{\mathrm{a}}$ \\
Mesitylene & 65 \\
3-Octanone & 85 \\
1-Heptanol & 86 \\
n-Butylbenzene & 56 \\
Trimethylpyridine & 54 \\
Phenol & $82^{\mathrm{a}}$ \\
o-Cresol & $95^{\mathrm{a}}$ \\
o-Ethylphenol & 105 \\
Napthalene & 68 \\
Dimethylnapthalene & 91 \\
Anthracene & 99 \\
d 10 -Anthracene. & 102 \\
Acridine & $78^{\mathrm{b}}$ \\
Carbazole & 101 \\
Pyrene & 105 \\
Average for 16 compounds & $84 \%$ \\
\hline a Average of two separate analyses. & \\
b 52\%'recovered in neutral and $25 \%$ in base \\
fraction.
\end{tabular}


of concentration levels of organic constituents. These compounds were phenol, cresol, xylene, trimethylpyridine, ethylphenol, naphthalene, anthracene, acridine, carbazole, and benzonitrile. Benzonitrile was studied more thoroughly and the results were published (Stamoudis et al., 1979).

\section{EXPERIMENTAL RESULTS}

\subsection{BIOLOGICAL REACTOR CHARACTERISTICS}

Table 3.1 summarizes general operating parameters and performance characteristics for the blological reactor employed for evaluation of the removal efficiencies of organic constituents. Data in Table 3.1 show that the biological reactor was managed with a mean bacterial-cell residence time of 15 days and a hydraulic residence time of 2 days: This practice resulted in a steady-state concentration of MLVSS of $1500 \mathrm{mg} / \mathrm{L}$ and a COD removal rate of $0.37 \mathrm{mg}$ COD removal/mg MLVSS-day. There was approximately $81 \%$ removal of $C O D$ and over $99.9 \%$ removal of phenolics as determined by the 4-aminoantipyrine colorimetric procedure. As shown below (Section 4.1), GC/MS analysis of composite effluent samples gave a lower average effluent: concentration for specific phenolic compounds than was measured by the colorimetric procedure. The blological reactor demonstrated that a high degree of nitrification was achieved. Approximately $78 \%$ of avallable nitrogen in influent was nitrified.

\subsection{REMOVAL EFFICIENCY OF ORGANIC CONSTITUENTS}

Total-ion chromatograms of the acid, base, and neutral fractions of the biological reactor influent and effluent are presented in Figs. 3.1-3.3. Visual comparisons reveal that activated-sludge treatment removed the bulk of the organic constituents.

Estimated influent and effluent concentrations and removal percentages of major extractable and chromatographable organic compounds identifled in the acid, base, and neutral fractions are presented in Tables 3.2-3.4. Because concentrations were estimated on the basis of total-ion counts referenced to several standard compounds, and because of possible losses due to extraction and separation procedures, it is belleved that reported concentration levels are only semiquantitative estimates ( $\pm 33-50 \%)$. Percentage removal values are considered to be more accurate than concentration values, because these estimates are basped on relative total-ion counts for the same compound (assuming similar extraction efficiencies for the compound in the reactor influent and effluent).

\section{DISCUSSION}

\subsection{ACID FRACTIONS.}

As shown in Table 3.2 the acid fraction of the quench water influent consisted almost exclusively of phenol and single-ring alkylated phenolic compounds. Phenol and cresols constitute the largest fraction of observed organics. The acid influent fraction represented more than $99.3 \%$ of the total identified organics on a mass basis. Despite the abundance of these 
Table 3.1 Average Biologlcal Reactor Performance Data for Evaluation of Removal of Trace Organic Compounds

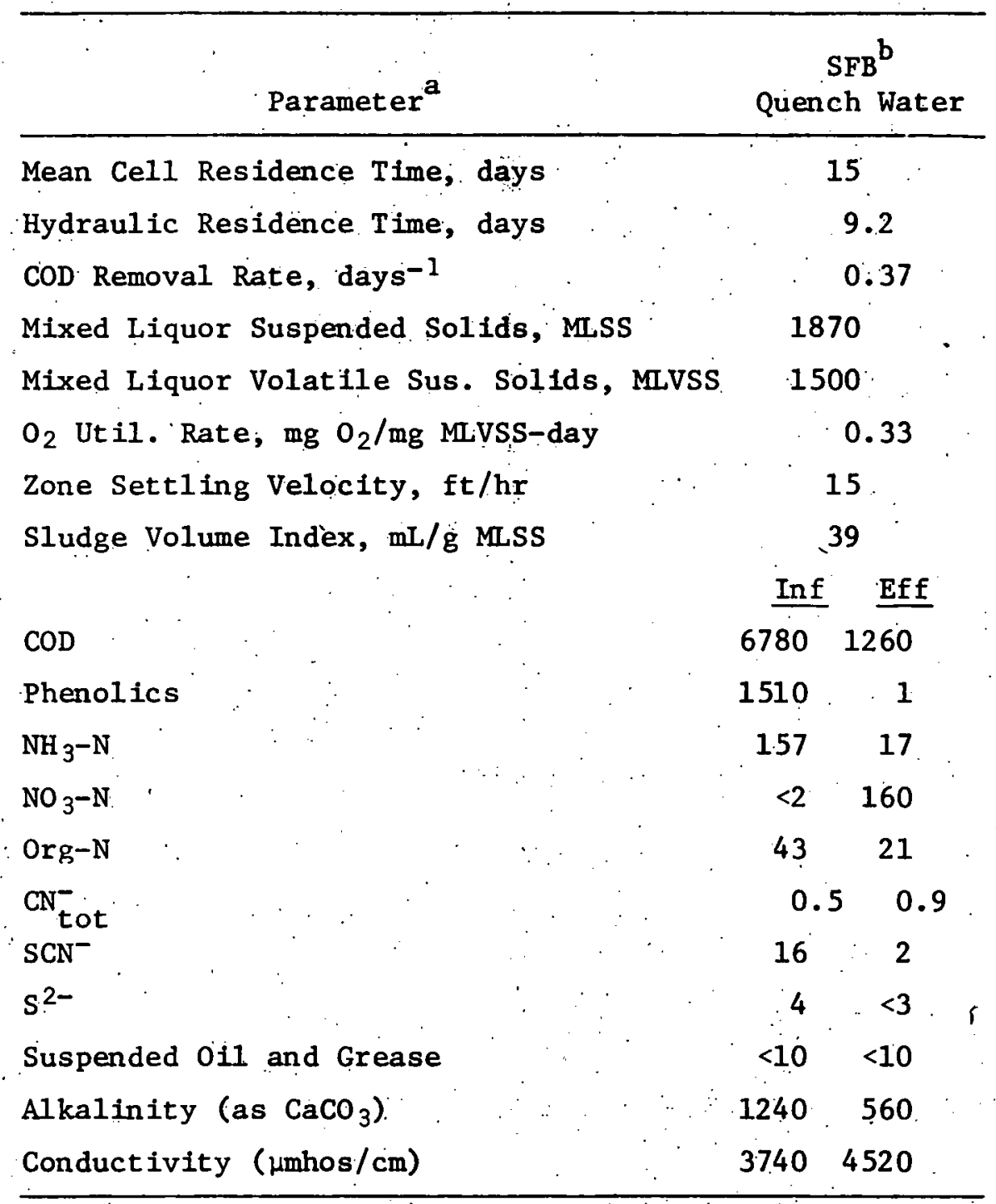

${ }^{a} \mathrm{All}$ units in $\mathrm{mg} / \mathrm{L}$ except as noted.

$b_{33 \%}$ strength ammonia stripped wast ewater. Data source: Luthy, Sekel and Talion (1979). 


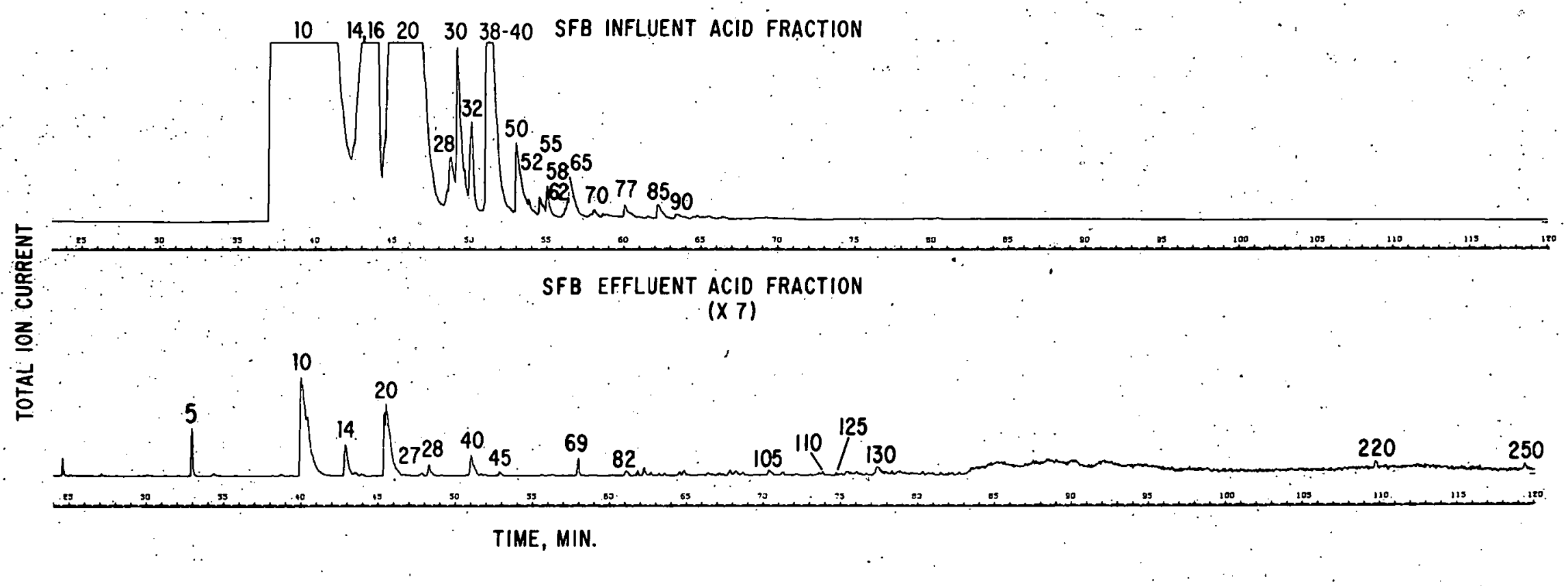

Fig. 3.1 Total-Ion Chromatograms of Influent and Effluent Acid-Fraction Extracts of Biologically Treated GPETC Slagging Fixed-Bed Coal-Gasification Quench Water 


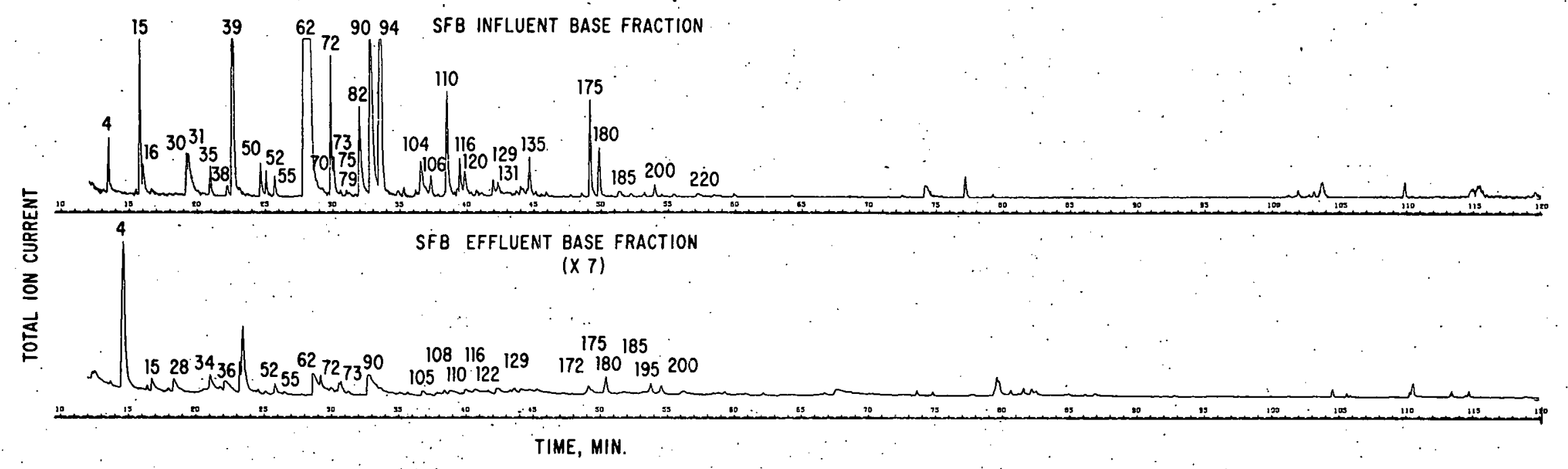

Fig. 3.2 Total-Ion Chromatograms of Influent and Effluent Base-Fraction Extracts of Biologically Treated GFETC Slagging Fixed-Bed Coal-Gasification Quench Water 


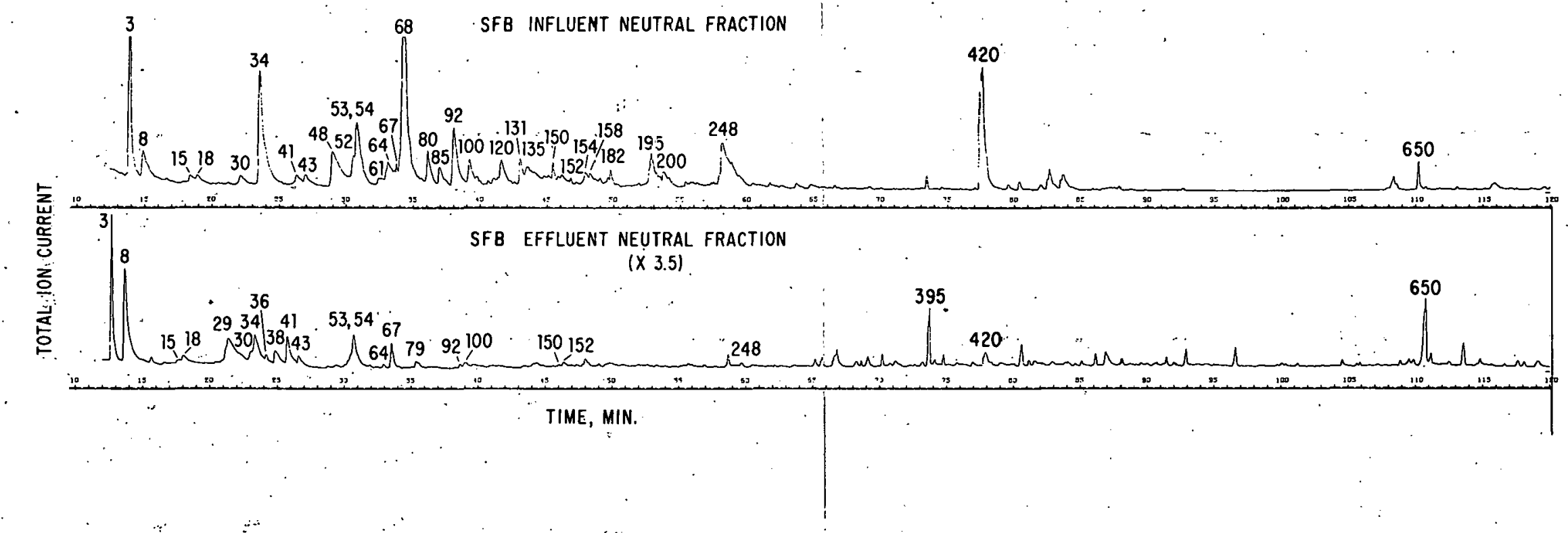

Fig. 3.3 Total-Ion Chromatograms of Influent and Effluent Neutral-Fraction Extracts of Biologically Treated GFETC Slagging Fixed-Bed Coal-Gasification Quench Water 
Table 3.2 Concentration in Biological Reactor Influent and Effluent and Percent Removal of Acid-Fraction Organics in GFETC Slagging, Fixed-Bed Coal-Gasification Quench Water

\begin{tabular}{|c|c|c|c|c|c|c|}
\hline Peak & No. & Compound Name & $\begin{array}{l}\text { Estimated } \\
\text { Influent Conc. } \\
\quad(\mu \mathrm{g} / \mathrm{L})^{\mathrm{a}}\end{array}$ & $\begin{array}{l}\text { Estimated } \\
\text { Effluent Con } \\
(\mu \mathrm{g} / \mathrm{L})^{\mathrm{b}}\end{array}$ & nc. & $\begin{array}{c}\text { Estimated } \\
\text { Percent } \\
\text { Removal }\end{array}$ \\
\hline 5 & & Dichlorobenzene & NT & 8 & & + \\
\hline 10 & & Phenol & $>500,000$ & 60 & & 99.99 \\
\hline $14 \&$ & 16 & Cresols & 30,000 & 12 & & 99.96 \\
\hline 18 & & Methoxypheno1 & ND & NT & & 100 \\
\hline 20 & & Cresol & $>150,000$ & 45 & & 99.97 \\
\hline 27 & & Methyl-met hoxyphenol & 50 & trace & & 100 \\
\hline 28 & & Ethylphenol & 870 & 4 & & 99.54 \\
\hline $30 \&$ & 31 & Dimethylphenols & 4,500 & trace & & 100 \\
\hline 32 & & Methyl-met hoxyphenol & 1,700 & $\mathrm{NT}$ & & 100 \\
\hline $38 \&$ & 40 & $\mathrm{C}_{2}$-Phenols & 12,500 & 7 & & 99.94 \\
\hline 50 & & $\mathrm{C}_{2}$-Phenol & 2,500 & 1 & & 99.96 \\
\hline 52 & & $\mathrm{C}_{3}$-Phenol & 70 & NT & & 100 \\
\hline $55 \&$ & 56 & $\mathrm{C}_{3}$-Phenols & 400 & $\mathrm{NT}$ & & 100 \\
\hline 58 & & $\mathrm{C}_{2}$-Methoxyphenol. & 430 & NT & & 100 \\
\hline $62-$ & 66 & $\mathrm{C}_{3}$-Phenols & 1,500 & $\mathrm{NT}$ & & 100 \\
\hline 69 & & Unknown & ND & 5 & & $\mathrm{ND} / \mathrm{PR}$ \\
\hline 70 & & $\mathrm{C}_{3}$-Phenol & 150 & NT & & 100 \\
\hline 77 & & $\mathrm{C}_{3} \mathrm{H}_{6}-\mathrm{Phenol}$ or Hydroxyind & 300 & NT & & 100 \\
\hline 82 & & $\mathrm{C}_{3} \mathrm{H}_{6}-\mathrm{Phenol}$ or Hydroxyind & ND & $<1$ & & $\mathrm{ND} / \mathrm{PR}$ \\
\hline 85 & & $\mathrm{C}_{3} \mathrm{H}_{6}-$ Phenol or Hydroxyind & 400 & NT & & 100 \\
\hline 90 & & $\mathrm{C}_{3} \mathrm{H}_{4}$-Pheno1 or Hydroxyind & 120 & NT & & 100 \\
\hline 105 & & $\mathrm{C}_{4} \mathrm{H}_{8}-\mathrm{Phenol}$ or Methyl-hyd & Iroxyindan ND & $<1$ & & $\mathrm{ND} / \mathrm{PR}$ \\
\hline 110 & & $\mathrm{C}_{4}$-Phenol & ND & $<1$ & & $\mathrm{ND} / \mathrm{PR}$ \\
\hline 125 & & $\mathrm{C}_{4}$-Phenol & ND & $<1$ & & $\mathrm{ND} / \mathrm{PR}$ \\
\hline 130 & & Naphthol & ND & $<1$ & & $\mathrm{ND} / \mathrm{PR}$ \\
\hline 220 & & Plastisizer (phthalate) & NT & $<1$ & & + \\
\hline 250 & & Plastisizer (phthalate) & NT & $<1$ & & + \\
\hline
\end{tabular}

ND, not determinable: NT, not detected. + ; found in "effluent only.

ND/PR stands for not-determinable/poorly-removed. Because the effluent contained fewer organics of lower concentration levels, the final extract volume had to be concentrated to a volume, much smaller than that of the influent. Certain peaks, corresponding to compounds that were in very low concentration levels in the influent, were then easier to identify in the effluent, but were obscured or in the. "noise" level in the influent.

${ }^{a}$ Undiluted ammonia-stripped quench water composition reported here.

${ }^{b}$ Actual biological reactor effluent concentrations were multiplied by 3 as reported here to factor out apparent removal owing to dilution. Thus all SFB effluent concentrations refer to an undiluted basis. 
Table 3.3 Concentration in Biological Reactor Influent and Effluent and Percent Removal of Base-Fraction Organics in GFETC Slagging, Fixed-Bed CoalGasification Quench Water

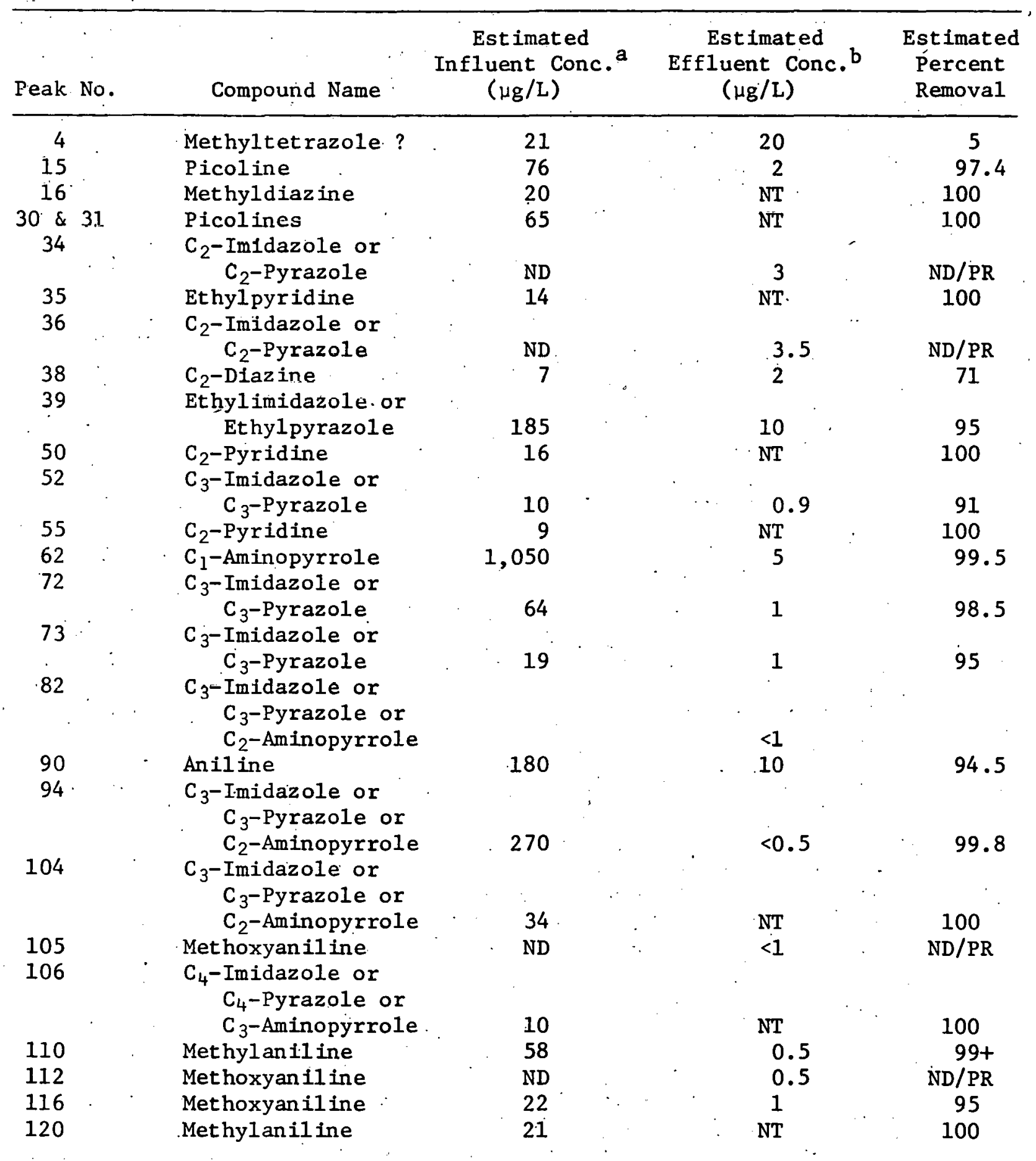


Table 3.3 (Contd.)

\begin{tabular}{lllcc}
\hline Peak No. & Compound Name & $\begin{array}{c}\text { Estimated } \\
\text { Influent Conc. } \\
(\mu \mathrm{g} / \mathrm{L})\end{array}$ & $\begin{array}{c}\text { Estimated } \\
\text { Effluent Conc.b } \\
(\mu \mathrm{g} / \mathrm{L})\end{array}$ & $\begin{array}{c}\text { Est imated } \\
\text { Percent } \\
\text { Removal }\end{array}$ \\
\hline 129 & Methoxyaniline & 10 & 1.5 & 85 \\
135 & C -Pyridine & 26 & 0.4 & 98.5 \\
175 & Quinoline & 57 & NT & 100 \\
180 & C 5 -Pyridine & 25 & 2 & 92 \\
185 & Isoquinoline & 6 & NT & 100 \\
200 & Methylquinoline & 7 & 1 & 83 \\
\hline
\end{tabular}

ND, not determinable. NT, not detected. ND/PR, not determinable/poorly removed, see note under Table 3.2

${ }^{a}$ See note a in Table 3.2.

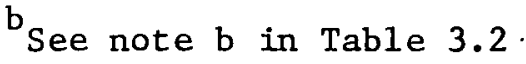

Table 3.4 Concentration in Biological Reactor Influent and Effluent and Percent Removal of Neutral-Fraction Organics on GFETC Slagging, Fixed-Bed CoalGasification Quench Water

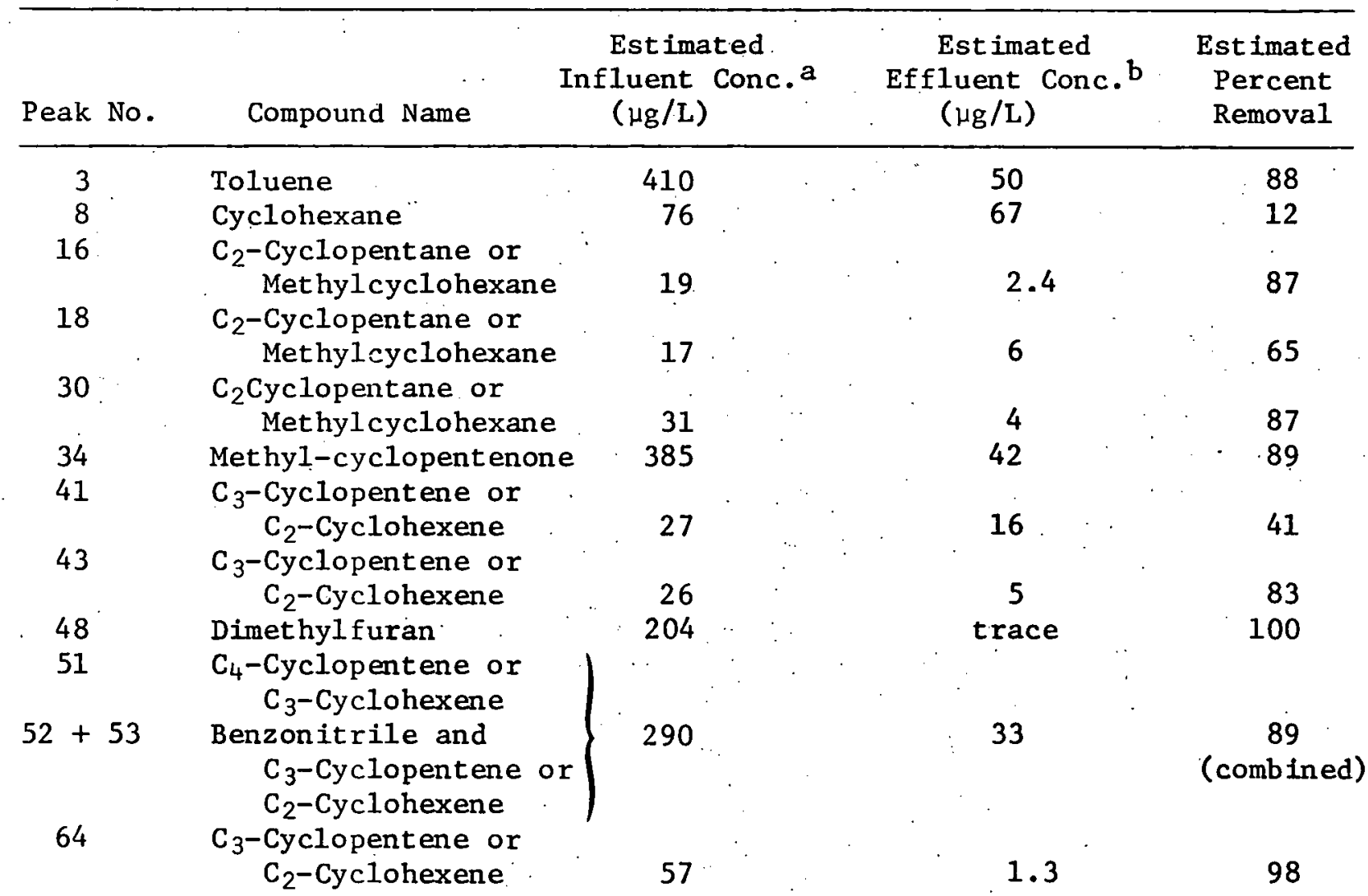


Table 3.4 (Contd.)

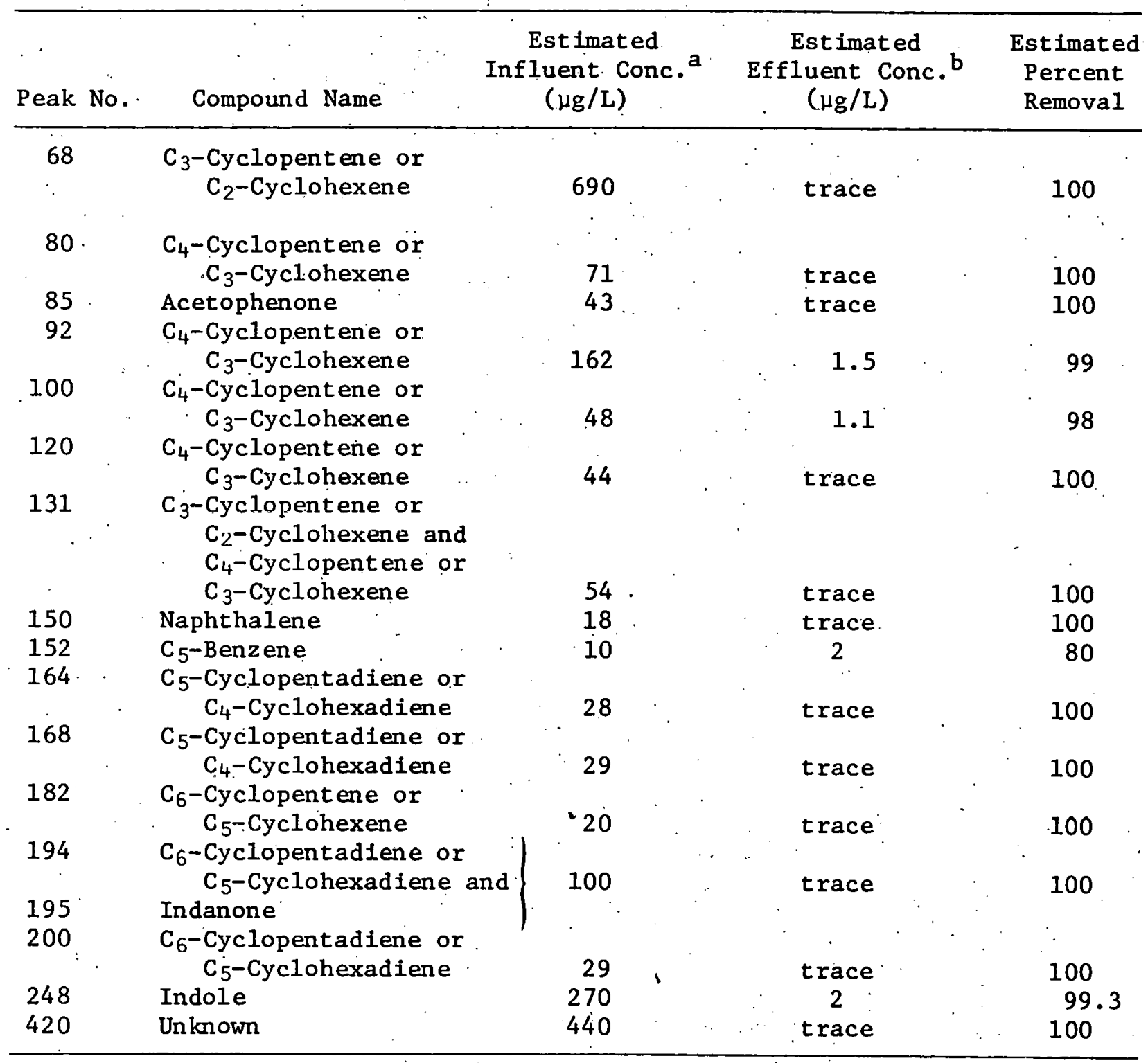

a See note a in Table 3.2.

${ }^{b}$ See note $b$ in Table 3.2 . 
compounds in the influent, only very small amounts of phenol, cresols, and certain higher substituted phenols or hydroxyindans were detected in the effluent. Overall removal efficiency for acid fraction organics was $>99.9 \%$. The effluent chromatogram showed a series of small peaks with retention times above $60 \mathrm{~min}$, corresponding to either alkylated phenols or alkylated hydroxyindans with olefinic substitutions. These compounds were not detectable in the influent because influent extract samples could not be analyzed effectively if the extract column was reduced to the small volume used for effluent samples.

\subsection{BASE FRACTIONS}

Table 3.3 shows that the base influent fraction consisted primarily of a series of nitrogen heterocyclic compounds, including alkylated aminopyrroles, imidazoles and/or pyrazoles, diazines, pyridines, quinolines, indoles, as well as aniline, alkylated anilines, and methoxyanilines. In general, removal efficiencies for these compounds were very good. The overall removal efficiency for base-fraction organics was over $96 \%$. Most of the peaks with retention times above $60 \mathrm{~min}$ in the influent and effluent base-fraction chromatograms (Fig. 3.2) were judged to be extraneous, and are attributed to plasticizers.

\subsection{NEUTRAL FRACTIONS}

As shown in Table 3.4, toluene and alkylated cycloalkanes and cycloalkenes were the dominant components of the influent neutral fraction. The influent also showed cycloalkenones, dimethylfuran, $\mathrm{C}_{5}$-benzene, benzonitrile, acetophenone, naphthalene, indanone, and indole. The removal of these compounds was generally very good with the exception of certain alkylated. cycloalkanes and cycloalkenes. Most of the peaks with retention times above $60 \mathrm{~min}$ (Fig. 3.3) were attributed either to plasticizers (Peak Nos. $395 \& 650$ correspond to phthalates) or to compounds with quite obscure spectra. These peaks may represent biological cellular metabolites, or products resulting from biological degradation. Peak No. 420 also could not be identified with certainty; the mass spectrum had two predominant masses (188 and 94).

\section{SUMMARY AND COMPARISON OF RESULTS WITH THE HYGAS STUDY}

This study showed that over $99 \%$ of the extractable and chromatographable organic material in the biological reactor influent consisted of phenols and alkylated phenols. These compounds were removed almost completely by activated-sludge treatment. These findings were similar to those observed in a previous investigation of HYGAS process water (Stamoudis et al., 1979).

In the HYGAS study it was found that the major components of the basefraction organics were aniline and alkylated anilines, pyridine and alkylated pyridines, quinolines, and indoles. However, the SFB base fraction, besides the presence of the above compounds, displayed as major components tetrazoles, aminopyrroles, imidazoles and/or pyrazoles, methoxyanilines, and diazines. Despite the marked compositional differences, the biological reactor removal efficiencies were good in both quench waters (overall removal $>90 \%$ for HYGAS, $>96 \%$ for $\mathrm{SFB}$ ). 
Organic compounds in the neutral fraction of the SFB biological reactor influent consisted mainly of toluene, benzonitrile, acetophenone, naphthalene, indole, and alkylated cycloalkanes and cycloalkenes. The GFETC neutral fraction sample did not possess the wide range of typical aromatic hydrocarbons observed in the study with HYGAS quench water. In general there were high removal efficiencies for SFB neutral-fraction organics, excepting certain alkylated dycloalkanes. It was observed in the HYGAS study that removal efficiency of neutral-fraction organics was dependent to a certain extent on chemical structure. The lack of a wide variety of aromatic hydrocarbons in SFB biological reactor influent precludes such observations for this process quench water. The variety of alkylated benzenes abundantly present in the HYGAS sample might be attributed to the use of toluene as a medium during the gasification process. Differences between quench water composition of HYGAS and SFB samples are attributable to differences in coal type, gasifier operating conditions, and other process variables.

\section{6 .CONCLUSIONS AND RECOMMENDATIONS}

Based on the results of this study it was concluded that over $99 \%$ of extractable and chromatographable organic material, on a mass basis, was represented in the acid fraction of process quench water from slagging, fixedbed coal gasification: The remaining organic material was represented in the basic and neutral fractions, with the former somewhat larger than the latter. Biological treatment removed almost all of the organics in the acid fraction, and over $96 \%$ and $93 \%$ of the organics in the base and neutral fractions, respectively. Removal efficiencies found in an earlier study of a HYGAS coalgasification process quench water were very similar, despite marked compositional differences in the base and neutral fractions.

Analytical data presented in the studies mentioned above are at best semiquantitative estimates.. In future work it is necessary to evaluate extraction efficiencies for organic compounds from the coal-gasification process effluents, with emphasis on compounds identified as hazardous by biological assays. Though not identifled by the GC/MS procedures employed here, recent reverse-phase, high-pressure, liquid chromatographic analysis of GFETC wastewater (Walters and Luthy, 1979) has shown the presence of polynuclear aromatic hydrocarbons. Therefore, it is recommended that special studies be conducted for evaluation of removal efficiencies of polynuclear aromatic hydrocarbons.

It is also recommended that future work evaluate the fate of trace organic compounds during wastewater pretreatment. These studies should simulate quench water pretreatment of solvent extraction and steam stripping.

It is recommended that additional studies be initiated to evaluate the extent to which trace organic compounds are being adsorbed on bacterial flocs rather than being degraded biologically. This work should include extraction of biological sludge in order to attempt mass balances for trace organic compounds. Work should also be initiated to evaluate improved removal efficiencies for trace base- and neutral-fraction organics. This work may include evaluation of powdered activated carbon addition to the biological reactor. 
Finaliy, it is recommended that emphasis in the analysis should be given to various fractions that were tested to be toxic and/or carcinogenic. by accepted biological tests.

\section{ACKNOWLEDGMENTS}

The authors acknowledge the assistance of a number of persons and their contributions to this study. Among these, of Argonne, are: Wyman Harrison and Kenneth Wilzbach who reviewed the manuscript; Leo Raphaelian who provided technical support; Sidney Bourne and Andrea Jirka who performed the extractions and fractionations; and William Sather who assisted with data reduction. Granville Batte of Mittelhauser Corporation also assisted with data reduction, and Leland E. Paulson of GFETC arranged for quench water collection and transport.

\section{REFERENCES}

Dark, W.A., Determination of Aromatic Hydrocarbons in a Biologically Treated Water from Coal Gasification using HPLC, presented at the ASTM Symposium on Analysis of Waters Associated with Alternate Fuel Production, Pittsburgh, Pa. (June 4-5, 1979).

Ellman, R.C., et al., Slagging Fixed-Bed Gasification Project Status at the Grand Forks Energy Technology Center, presented at the 1979 Lignite Symposium, Grand Forks, N. Dak. (May 30-31, 1979).

Luthy, R.G., and J.T. Tallon, Experimental Analysis of Biological Oxidation Characteristics of HYGAS Coal Gasification Wastewater, Carnegie-Mellon University Report to U.S. Department of Energy, FE-2496-27 (1978).

Luthy, R.G., D.J. Sekel, and J.T. Tallon, Biological Treatment of Grand Forks Energy and Technology Center Slagging Fixed-Bed Coal Gasification Process Wastewater, Carnegie-Mellon University Report to U.S. Department of Energy, FE-2496-42 (1979).

Raphaelian, L., and W. Harrison, Stability of Extractable Constituents in Stored Samples of Gasification Condensates Inferred from Comparison of Total Ion Chromatograms, Argonne National Laboratory Report ANL/EMR-3 (1979).

Singer, P.E., et al., Assessment of Coal Conversion Wastewaters: Characterization and Preliminary Biotreatability, U.S. EPA Report EPA-600/7-78-181 (1978).

Singer, P.E., et al., Evaluation of Coal Conversion Wastewater Treatability, presented at the Fourth Symposium on Environmental Aspects of Fuel Conversion Technology, Hollywood, Fla. (April 1979).

Stamoudis, V.C., R.G. Luthy, and W. Harrison, Removal of Organic Constituents in a Coal Gasification Process Wastewater by Activated Sludge Treatment, Argonne National Laboratory Report ANL/WR-79-1 (1979). 
Walters, R.W., and R.G. Luthy, Unpublished Information

White, C.M., and C.E. Schmidt, Analysis of Volatile Polar Organics in Untreated By-Product Waters from Coal Conversion Processes, American Chemical Society, Div. of Fuel Chemistry, 23(2):134 (1978). 


\section{Distribution for ANL/PAG-1}

\section{Internal:}
A. Antonopoulos
S. Bourne
R. P. Carter
E. J. Croke
P. Cunningham
S: Danyluk
J. D. Ditmars
J. Dzingel.
R. D. Flotard
D. Grahn
L. Habegger
J. Harkness

W. Harrison (10)

J. J. Roberts

D. A. Haugen

D. M. Rote

L. J. Hoover

N. Sather

A. Jirka

D. O. Johnson

W. Sinclair

A. B. Krisciunas

V. C. Stamoudis (40)

K. S. Macal

W. E. Massey

J. Stetter (10)

D. L. McCown

S. Vargo (10)

D-P Wang

E. G. Pewitt

L. A. Raphaelian

K. Wilzbach (3)

C. A. Reilly

ANL Contract Copy

ANL Libraries (5)

TIS Files (6)

\section{External:}

DOE-TIC, for distribution per UC-90c (278)

Manager, Chicago Operations and Regional Office, DOE

Chief, Office of Patent Counsel, DOE-CORO

President, Argonne Universities Association

Energy and Environmental Systems Division Review Committee:

E.E. Angino, U. Kansas

R.E. Gordon, U. Notre Dame

W.W. Hogan, Harvard U.

L.H. Roddis, Jr., Charleston, S.C.

G.A. Rohlich, U. Texas at Austin

R.A. Schmidt, Booz, Allen \& Hamilton

Jack Abrahams, Fossil Energy Program, USDOE (3)

Katherine Alben, N.Y. Dept. of Health, Albany, NY

Louis Anastasia, Inst. Gas Technology, Chicago, IL

Thomas Atkins, Mittelhauser Corp.; Downers Grove, IL (3)

Robert A. Baker, USGS, Water Resources Div., NSTL Station, MS

M.L. Bender, Dept. of Chemistry, Northwestern Univ., Evanston, IL

Rudolf Bieri, Virginia Institute of Marine Science, Gloucester Pt., VA

Richard Biljetina, Environmental Eng., Inst. Gas Technology, Chicago, IL

Bill Brewer, Dept. of Bio. Sciences, Wright State Univ, Daytọn, OH

Mayo Carrington, Fossil Energy Program, USDOE (3)

John C. Craun, Environmental Res. \& Tech., Pittsburgh, PA

Stephen A. Dudley, Normandeau Assoc., Bedford, NH

Paul Duhamel, Biomedical \& Environmental Res., USDOE

Jackson E1lington, EPA, Athens, GA

Dick Engen, ITT Rayonier, Shelton, WA

Davis Ford, Engineering-Science, Aust in, TX

C.S. Giam, Chemistry Dept., Texas A\&M, College Station, TX

J.H. Gibbons, Office of Technology Assessment, U.S. Congress

Stephen E. Herbes, ORNL, Oak Ridge, TN

Michael Hoffmann, Univ. of Minnesota, Minneapolis, MN 
Ami Horowitz, Dept. of Soil Sci., Michigan State Univ., E. Lansing, MI Philip H. Howard, Syracuse Research Corp., Syracuse, NY

Doug Johnson, Univ. of Tenn., Knoxville, TN

G.J. Karabatsos, Dept: of Chemistry, Michigan State Univ., E. Lansing, MI D. E. Kash, USGS, Reston, VA

Library, Virginia Inst. of Marine Science, Gloucester Pt., VA

Richard G. Luthy, Carnegie-Mellon Univ., Pittsburgh, PA (20)

M.J. Massey, Environmental Res. \& Tech., Pittsburgh, PA (2)

H. M. Mehendale, Dept. of Pharm. \& Toxi., Univ. of Miss:, Jackson, MS Calvin Menzie, FWS/FER, USDI, Washington, D.C.

Roger A. Minear, Dept. of Civil Eng., Univ. of Tenn., Knoxville, TN

Leslie Nelken, Arthur D. Little, Cambridge, MA

Doris F. Paris, EPA-ERL EPB, Athens, GA

Leland E. Paulson, USDOE, GFETC, Grand Forks, ND (3)

Harriette L. Phelps, Univ. of D.C., Washington, D.C.

D. Rapisarda, DuPont-Biochemicals, Wilmington, DE

David Schultz, USGS, NSTL Station, MS

Jack P. Schwartz, Inst. of Marine Sciences, Univ. of Alaska, Fairbanks, AK D.G. Shaw, Inst. of Marine Sciences, Univ, of Alaska, Fairbanks, $A K$

M.S. Simmons, Dept. of Env. \& Ind. Health, Univ. of Mich., Ann Arbor, MI Philip Singer, Univ. of North Carolina, Chapel Hill, NC

Vernon Snoeyink, Dept. of Civil Eng., Univ. of Ill., Urbana, IL

George Stapelton, Dept. of Biomed \& Environmental Res., USDOE, Washington, D.C.

R.R. Stephenson, Tunstali Lab., Sittingbourne Kent, England

G. Stout, Water Res Ctr., Univ. of I11., Urbana, IL

Daniel P. Thoman, The Mitre Corp., McLean, VA

Armand Thomas, A.F. Meyer Assoc., McLean, VA

W. Tsang, Nat1. Bureau of Standards, Washington, D.C.

Kurt White, Pittsburgh Energy Technology Center, USDOE, Pittsburgh, PA

Fred Witmer, Div. of Envir. Control Tech., USDOE, Washington, D.C.

Richard C. Young, Aquatic Tox. Lab-U.S. TVA, EDB, Muscle' Shoals; AL 